\title{
PELUANG DAN TANTANGAN PELAKSANAAN PIDANA ISLAM DI INDONESIA
}

\author{
Massadi $^{1}$ \\ Hakim Pengadilan Agama Unaaha \\ Jl. Inolobunggadue, Konawe, Sultra, Indonesia. \\ Email: ${ }^{1}$ adjie.massadi@gmail.com
}

\begin{abstract}
This study discusses the opportunities and challenges of the implementation of Islamic criminal law in Indonesia, which parenthetically is the rule of law. This study examines the opportunities and challenges of applying criminal law in Indonesia. The portrait of Islamic criminal law that is understood by some people is cruel and inhuman, even though such an impression arises because it is not seen as a whole. Islamic criminal law which is part of Islamic law, for example the law of cutting off the hands is often accused of being too cruel and unfair. Though this punishment was only handed down when a number of strict requirements were met. Islamic criminal law has the opportunity to be applied when the principle of law enforcement has a deterrent effect. However, if law enforcement is seen as merely pragmatic and a place to dictate something that is unclear, then Islamic criminal law cannot be applied.
\end{abstract}

Keywords: Opportunity, Challenges, Islamic Criminal Law.

\begin{abstract}
Abstrak
Kajian ini membahas peluang dan tantangan pelaksanaan pidana Islam di Indonesia yang notabenenya adalah Negara hukum. Kajian ini menelaah peluang dan tantangan penerapan hukum pidana di Indonesia. Potret hukum pidana Islam yang dipahami sebagian orang adalah kejam dan tidak manusiawi, padahal kesan semacam itu muncul karena tidak melihat secara utuh dan menyeluruh. Hukum pidana Islam yang merupakan bagian dari syariat Islam, misalnya hukum potong tangan sering dituding terlampau kejam dan tidak adil. Padahal hukuman ini baru dijatuhkan ketika sejumlah persyaratan yang ketat terpenuhi. Hukum pidana Islam mempunyai peluang untuk diterapkan bilamana prinsip penegakan hukum memberikan efek jerah. Namun bila penegakan hukum dipandang sebagai pragmatis semata dan ajang untuk mendialokkan sesuatu yang tidak jelas hukumnya, maka hukum pidana Islam tidak mampu diterapkan.
\end{abstract}

Kata Kunci: Peluang, Tantangan, Pidana Islam. 


\section{PENDAHULUAN}

Masalah hukum pidana hadir sebagai isu yang paling kontroversial dalam perdebatan tentang penerapan hukum Islam. Sejumlah problem hukum materil, pembuktian dan prosedur (hukum acara) muncul karena prospek implementasi cabang syariat ini. Di tengah berkembangnya keinginan untuk menerapkan hukum pidana Islam, ada isu-isu penting yang harus didiskusikan yaitu tentang adanya prakondisi penegakan hukum pidana Islam dan berharap dapat memberikan semangat dalam melaksanakan ajaran Islam yang telah jauh ditinggalkan.

Disadari pula bahwa dewasa ini sering kali umat Islam dibingungkan oleh keanekaragaman mazhab hukum. Munculnya berbagai pendapat di bidang hukum Islam di satu pihak menimbulkan kesan tidak adanya kepastian hukum yang mesti dianut dan di lain pihak menyediakan berbagai alternatif yang bisa dipilih sesuai dengan kondisi kata hati pemeluk Islam. Oleh karena itu, upaya yang luwes ialah memunculkan kajian perbandingan mazhab dengan mengajukan masalah serta pendapat dari setiap mazhab dengan argumentasi masing-masing. Setelah itu dilakukanlah analisis dan penetapan pendapat yang dinilai lebih kuat argumentasinya. Cara ini merupakan upaya terobosan menembus kebekuan ijtihad.

Upaya serupa ini dilakukan pula oleh masyarakat Indonesia seperti didirikannya Majlis Tarjih oleh Muhammadiyah. ${ }^{1}$ Namun, upaya seperti ini masih terbatas pada bidang-bidang tertentu sehingga belum ada putusan yang sama dan berlaku untuk suatu kawasan nusantara. Dengan demikian, upaya kompilasi hukum Islam yang akan menjadi referensi utama para hakim di negeri ini menjadi amat penting serta mendapat topangan metodologi hukum yang kuat dan jelas.

Kajian ini, mencoba untuk mengulas tentang bagaimana Peluang dan Tantangan Penerapan Hukum Pidana Islam khususnya di Indonesia. Pidana Islam mencuak kepermukaan sebagai sebuah resolusi dalam pelbagai persoalan hukum

\footnotetext{
${ }^{1}$ Juhaya S. Praja. Hukum Islam di Indonesia: Pemikiran dan Praktek (Bandung: PT. Remaja Rosdakarya, 1991), h. 26.
} 
yang dihadapi oleh hakim. Termasuk di pengadilan agama, dalam kasus hamil di luar nikah dan kemudian dijadikan sebagai alasan untuk mendapatkan dispensasi nikah. Kasus serupa banyak ditemui dan bahkan sudah menjadi rahasia umum, kondisi demikan kian beralarut-larut disebabkan tidak adanya efek jerah bagi pelaku. Pelaku zina dengan mudahnya diberikan legalitas untuk menikah tanpa ada hukuman sedikitpun sebagai tebusan atas perilakunya. Pada hal dalam hukum pidana Islam, pelaku zina dikenakan hukum cambuk atau rajam. Keadaan demikian menjadi dasar pijakan untuk melihat peluang dan tantangan penerapan hukum pidana Islam dalam bingkai hukum Nasional, sebagai solusi atas persoalan yang membelit.

\section{PEMBAHASAN}

\section{Aspirasi Pemberlakuan Pidana Islam}

Berbicara tentang penerapan pidana Islam, teringat berbagai gerakangerakan Islam yang tidak pernah lelah menyuarakan pemberlakuannya, mulai dari mereka yang tergolong radikal sampai moderat. Mulai dari yang menginginkan penerapan itu sekarang juga sampai pada yang memberikan toleransi terhadap penerapan secara bertahap atau setelah siap infrastrukturnya. Ini menunjukkan bahwa dikalangan internal Islam sendiri terdapat berbagai versi yang muncul dengan berbagai aspirasi dalam menanggapi isu kemungkinan diberlakukannya hukum pidana Islam di Indonesia.

Perdebatan mengenai peluang penerapan pidana Islam di Indonesia, tampaknya merupakan polemik yang tak pernah berkesudahan sejak sidang BPUPKI/PPKI pada tahun 1945. Pada masa pasca Orde Baru, tema ini muncul kembali melalui perdebatan tentang perlunya amandemen Pasal 29 UUD. Fraksi Partai Persatuan Pembangunan (F-PPP) dan Fraksi Partai Bulan Bintang (F-PBB) dalam pemandangan umum mereka bersikeras untuk memasukkan kembali Piagam Jakarta dalam Batang Tubuh UUD 1945, khususnya Pasal 29. ${ }^{2}$

2 Lihat, Arskal Salim, Penerapan Syariat Bukan Negara Islam, dalam http://www.islamlib.com 
Penerapan pidana Islam sebetulnya bukanlah hal baru. Sejak lama dipraktekkan oleh beberapa negara muslim, seperti Arab Saudi, Afghanistan, dan Sudan. UU Islam di negara-negara ini secara keras diberlakukan, terutama menyangkut hukum pidana ( $h u d u d$ ). Agaknya, persoalan pidanalah yang menjadi ciri khas apakah sebuah negara muslim dianggap menerapkan hukum Islam atau tidak. Dalam sistem hukum Indonesia, dikenal berbagai sumber hukum nasional yang berasal dari hukum adat, hukum Islam dan hukum barat. Ketiga sumber hukum tersebut selalu berlomba untuk menjadi hukum nasional sehingga berlakulah berbagai teori hukum. ${ }^{3}$

Sesungguhnya UUD 1945 sangat akomodatif terhadap kepentingan warga negara dalam menjalankan ibadahnya. Dalam perspektif tata hukum Indonesia, fungsi negara adalah melindungi setiap agama dan pemeluknya melalui peran menjamin pelaksanaan ibadah, memberikan dukungan fasilitas dan menjaga kerukunan antarumat beragama. Agama haruslah menjadi landasan moral, karenanya setiap peraturan dan perundang-undangan yang bertentangan dengan moral dan agama mesti dikesampingkan. Secara normatif, menjalankan syariat Islam secara kaffah merupakan perintah Allah, dan mengabaikannya dikategorikan sebagai manusia kafir, zalim atau fasik. ${ }^{4}$

Dalam benak beberapa kelompok Islamis, hukum Islam memiliki kesakralan yang tidak bisa diganggu gugat. Terutama menyangkut hukum yang diatur dengan ayat-ayat yang qath'i. Melawan atau memberikan tafsiran lain terhadap ayat-ayat tersebut bisa dianggap sebagai kekufuran. Pemahaman Islam yang masih tradisional tampaknya masih menyilimuti cara pandang masyarakat pada umumnya. Meski demikian, masyarakat Islam secara luas nampaknya kurang begitu bersemangat dengan isu penerapan hukum Islam ini, apatah lagi penerapan hukum pidana Islam.

\footnotetext{
${ }^{3}$ A.Rahmat Rosyadi, dan H. M. Rais Ahmad, Formalisasi Syariat Islam dalam Perspektif Tata Hukum Indonesia (Edisi: I; Bogor: Ghalia Indonesia, 2006), h. 9.

${ }^{4}$ A.Rahmat Rosyadi, dan H. M. Rais Ahmad, Formalisasi Syariat Islam..., h. 31.
} 


\section{Potret Hukum Pidana Islam}

Hukum pidana Islam yang kerap tergambar di media massa adalah kejam dan tidak manusiawi, padahal kesan semacam itu muncul karena tidak melihat secara utuh dan menyeluruh. Hukum pidana Islam merupakan bagian dari syariat Islam, misalnya hukum potong tangan sering dituding terlampau kejam dan tidak adil. Padahal hukuman ini baru dijatuhkan ketika sejumlah persyaratan yang ketat terpenuhi.

Hukum pidana Islam dikenal beberapa asas-asas penting seperti asas legalitas, asas tidak berlaku surut, asas praduga tak bersalah, tidak sahnya hukum karena keraguan, prinsip kesamaan dihadapan hukum. Sehubungan dengan hal ini, para ahli hukum pidana barat mengklaim bahwa asas-asas di atas berasal dari hukum pidana mereka dan ini dianggap tidak adil. Hal itu disebabkan, lebih dari 14 abad hukum pidana Islam telah menjadi pionir dalam penerapannya dengan landasan yang valid, yakni Alquran dan Sunnah Nabi Muhammad Saw. Dalam sejarah umat Islam, banyak peristiwa hukum pidana Islam yang dipraktekkan.

Pembuat hukum pidana Islam tidak menyusun ketentuan-ketentuan hukum dari syariat tanpa tujuan apa-apa, melainkan terdapat tujuan tertentu yang luas. Dengan demikian, untuk memahami pentingnya suatu ketentuan, mutlak perlu diketahui apa tujuan dari ketentuan itu. Para ahli hukum Islam mengklasifikasikan tujuan-tujuan yang luas dari syariat sebagai berikut:

a) Menjamin keamanan dari kebutuhan-kebutuhan hidup merupakan tujuan pertama dan utama dari syariat. Apabila kebutuhan-kebutuhan ini tidak terjamin, akan terjadi kekacauan dan ketidaktertiban dimana-mana.

b) Menjamin keperluan hidup (keperluan sekunder).

c) Membuat berbagai perbaikan yaitu menjadikan hal-hal yang dapat menghiasi kehidupan sosial dan menjadikan manusia mampu berbuat dan mengatur urusan hidup lebih baik. ${ }^{5}$

\footnotetext{
${ }^{5}$ Topo Santoso, Membumikan Hukum Pidana Islam (Jakarta: Gema Inasani, 2003), h. 45.
} 
Klasifikasi kejahatan dalam hukum pidana Islam terbagi dalam tiga bagian yaitu: hudud, qishash dan ta'zir. Kejahatan hudud adalah kejahatan yang paling serius dan paling berat dalam hukum pidana Islam. Kejahatan dalam kategori ini diancam dengan hukuman hadd, yaitu hukuman yang ditentukan sebagai hak Allah, dalam arti kuantitas dan kualitasnya ditentukan dan ia tidak mengenal tingkatan.

\section{Konsep Pemberlakuan Hukum}

\section{a. Hukum Islam Tentang Penataan Hukum}

Syariat Islam adalah wahyu Allah yang diturunkan kepada Rasulullah untuk disampaikan kepada umatnya. Ia bukan sebuah teori, tetapi merupakan ajaran ilahi yang harus dipelajari dan diberlakukan untuk menciptakan keteraturan dalam kehidupan masyarakat serta keseimbangan antara kewajiban dan hak. Syariat Islam akan berlaku bagi semua umat manusia di dunia sampai akhirat, tetapi bila syariat Islam dijadikan hukum positif disuatu negara, maka keberlakuannya hanya bagi masyarakat Islam. Ajaran tentang penataan hukum dalam kajian ilmu hukum memang merupakan sebuah teori yang dikemukakan oleh ahli hukum berdasarkan proses hukum yang terjadi di masyarakat, tetapi dari segi syariat Islam hal itu tidak saja disebut sebagai teori melainkan merupakan prinsip yang wajib diberlakukan. ${ }^{6}$

Secara konseptual terdapat prinsip-prinsip syariat Islam yang mencakup penataan dan penerapan hukum Islam. Bahwa Allah dan Rasulnya memerintahkan kepada orang yang beriman agar menjalankan hukumnya. ${ }^{7}$

\footnotetext{
${ }^{6}$ Topo Santoso, Membumikan Hukum Pidana Islam, h. 2. “...Barangsiapa yang tidak memutuskan menurut apa yang diturunkan Allah, maka mereka itu adalah orang-orang yang kafir”, (QS al-Maidah/5:44). “...Barangsiapa tidak memutuskan perkara menurut apa yang diturunkan Allah, maka mereka itu adalah orang-orang yang zalim”, (QS al-Maidah/5:45), “...Barangsiapa tidak memutuskan perkara menurut apa yang diturunkan Allah, maka mereka itu adalah orang-orang yang fasik", (QS al-Maidah/5:47).

${ }^{7}$ H. Ichtijanto S.A, Pengembangan Teori Berlakunya Hukum Islam di Indonesia, dalam: Hukum Islam di Indonesia, Perkembangan dan Pembentukan (Bandung: Remaja Rosdakarya, 1991), h. 95.
} 
Para ahli hukum di Indonesia mempelajari tentang teori-teori penerapan hukum Islam melalui sistem hukum yang pernah berlaku di Indonesia selama masa kolonial Belanda. Adanya teori-teori ini menggambarkan, betapa akrabnya hukum Islam dengan penduduk, masyarakat, dan bangsa Indonesia. Hal ini merupakan indikator bagaimana perjuangan masyarakat Indonesia yang beragama Islam ingin memberlakukan syariat Islam sesuai perintah Allah dan Rasulnya. ${ }^{8}$

Membicarakan tentang teori-teori permberlakuan hukum Islam, maka akan sangat berkaitan dengan proses bagaimana unsur-unsur hukum Islam itu dapat menjadi hukum positif atau bagian dari hukum nasional, di samping hukum adat dan hukum Barat. Adanya politisasi hukum yang dilakukan oleh kolonial Belanda ke arah mereduksi syariat Islam serta menjauhkan dari masyarakatnya, menyebabkan hukum Islam sampai saat ini selalu terpinggirkan dalam proses

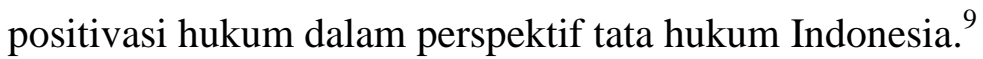

Ajaran Islam tentang penataan hukum memberi gambaran, bagaimana sesungguhnya Islam telah menata kehidupan manusia ini dengan hukum-hukum yang telah ditetapkan. Teori atau ajaran tentang penataan hukum menurut perspektif Islam bersumber dari Allah sebagai pencipta syari'at dalam bentuk wahyu, yaitu Alquran. Ia merupakan hukum normatif bersifat universal dan berlaku untuk seluruh manusia tanpa membedakan kedudukan, ras, politik, dan sosial-budaya. Keuniversalan hukum Alquran itu memerlukan penjelasan dalam bentuk implementasi hukum yang bersifat praktis. Hal ini dilakukan Rasulullah melalui kehidupan sehari-hari dalam bentuk hukum normatif bersifat aplikatif, yaitu As-Sunnah. ${ }^{10}$ Manakalah terjadi ketiadaan atau ketidakjelasan hukum yang dimaksud oleh Allah dan rasulnya dalam Alquran dan as-sunnah, maka pembentukan hukumnya diserahkan kepada manusia, melalui metode ijtihad.

\footnotetext{
${ }^{8}$ A. Rahmat Rosyadi dan H.M. Rais Ahmad, Formalisasi Syariat Islam...h. 67

${ }^{9}$ A. Rahmat Rosyadi dan H.M. Rais Ahmad Formalisasi Syariat Islam...h. 68.

${ }^{10}$ A. Rahmat Rosyadi dan H.M. Rais Ahmad, Formalisasi Syariat Islam...h. 68.
} 
Ajaran tentang penataan hukum ini menyatakan bahwa bagi setiap orang yang beriman agar menjalankan syari'atnya secara kaffah. ${ }^{11}$ Beberapa prinsip yang tercantum dalam Alquran tentang penataan dan penerapan hukum Islam, menegskan bahwa orang Islam pada dasarnya diperintahkan supaya taat kepada Allah dan rasulnya serta kepada pemerintah. Orang Islam tidak dibenarkan mengambil pilihan hukum lain manakala Allah dan rasulnya telah menetapkan hukum yang pasti dan jelas. ${ }^{12}$ Apabila mengambil pilihan hukum selain syariat Islam, maka dianggap zalim, kafir, dan fasik. ${ }^{13}$ Oleh karena itu, dari segi syariat Islam semestinya berlaku teori penataan hukum bahwa setiap orang Islam berlaku hukum Islam dan wajib menjalankannya sebagai tuntutan akidah.

Oleh karena itu, tanpa dikaitkan dengan keberadaan hukum di masyarakat, umat Islam harus tetap berpegang kepada prinsip bahwa bagi orang Islam berlaku hukum Islam. Apabila ternyata dalam masyarakat ada norma-norma hukum adat atau hukum Barat, dengan kekuatan otoritas yang sama atau lebih kuat, maka akan muncul masalah hubungan sistem hukum. Hukum mana yang akan diterapkan dalam lingkungan masyarakat. Hal ini sangat tergantung pada politik hukum pemerintah atau politik hukum dalam konstitusi negara. Ketaatan orang Islam terhadap pemerintah dalam menjalankan hukumnya merupakan bagian dari teori penataan hukum atau prinsip syariat Islam juga. ${ }^{14}$ Dalam posisi ini, maka ketaatan

\footnotetext{
11،Hai orang-orang yang beriman, masuklah kamu ke dalam Islam secara keseluruhan, dan janganlah kamu turut langkah-langkah syaitan. Sesungguhnya syaitan itu musuh yang nyata bagimu." (QS al-Baqarah/2:208)

12،'Dan tidaklah patut bagi laki-laki yang mukmin dan tidak (pula) bagi perempuan yang mukmin, apabila Allah dan Rasul-Nya telah menetapkan suatu ketetapan, akan ada bagi mereka pilihan (yang lain) tentang urusan mereka. Dan barangsiapa mendurhakai Allah dan Rasul-Nya maka sungguhlah dia telah sesat, sesat yang nyata." (QS al-Ahzab/33:36)

13،...Barangsiapa yang tidak memutuskan menurut apa yang diturunkan Allah, maka mereka itu adalah orang-orang yang kafir", (QS al-Maidah/5:44). “...Barangsiapa tidak memutuskan perkara menurut apa yang diturunkan Allah, maka mereka itu adalah orang-orang yang zalim”, (QS al-Maidah/5:45), “...Barangsiapa tidak memutuskan perkara menurut apa yang diturunkan Allah, maka mereka itu adalah orang-orang yang fasik”, (QS al-Maidah/5:47)

14،"Hai orang-orang yang beriman, taatilah Allah dan taatilah Rasul (Nya), dan ulil amri di antara kamu. Kemudian jika kamu berlainan pendapat tentang sesuatu, maka kembalikanlah ia kepada Allah (Alquran) dan Rasul (sunnahnya)..." (QS an-Nisaa'/4:59)
} 
terhadap pemerintah dalam memberlakukan hukum positif yang bersumber dari hukum adat dan hukum Barat, bagi umat Islam harus bersifat selektif, sepanjang hukum itu tidak bertentangan secara prinsipil dengan syariat Islam.

\section{b. Hukum Islam dan Teori Penerimaan Otoritas Hukum}

Teori Penerimaan Otoritas Hukum diperkenalkan oleh seorang orientalis Kristen, H.A.R. Gibb, dalam bukunya The Modern Trends of Islam, seperti dikutip H. Ichtijanto bahwa orang Islam jika menerima Islam sebagai agamanya, ia akan menerima otoritas hukum Islam kepada dirinya. Berdasarkan teori ini, secara sosilogis, orang yang memeluk Islam akan menerima otoritas hukum Islam dan taat dalam menjalankan syariat Islam. Namun ketaatan ini akan berbeda satu dengan lainnya, dan sangat bergantung pada tingkat ketakwaan masing-masing.

Selain Gibb, Charles J. Adams ${ }^{15}$ mengungkapkan bahwa hukum Islam merupakan subjek terpenting dalam kajian Islam karena sifatnya yang menyeluruh; meliputi semua bidang hidup dan kehidupan muslim. Berbeda dengan cara mempelajari hukum -hukum lain, studi tentang hukum Islam memerlukan pendekatan khusus, sebab yang termasuk bidang hukum Islam itu bukan hanya apa yang disebut dengan istilah law dalam hukum Eropa, tetapi juga termasuk masalah sosial lain di luar wilayah yang dikatakan law itu.

Sebagai sebuah fakta yang terjadi pada masyarakat yang telah menerima Islam bahwa semua orang Islam akan terus menjalankan syariat berdasarkan akidah yang dianutnya. Akan sangat sulit memisahkan masyarakat Islam dengan syariatnya yang menjadi tuntutan hukum dan moral dalam kehidupannya. Pada masyarakat Indonesia yang keislamannya dianut oleh fanatisme ajaran atau ketokohan, akan selalu mempertahankan syariat dan akidahnya sampai mati. ${ }^{16}$

Hukum Islam tidak dapat dilepaskan dari agama Islam dan tidak dapat dipisahkan dari masyarakat Islam. Bahkan sebagaimana dikatakan Gibb, hukum

\footnotetext{
${ }^{15}$ Charles J. Adams, dalam Muhammad Daud Ali, Hukum Islam, Pengantar Ilmu Hukum dan Tata Hukum Islam di Indonesia (Cet. VII; Jakarta: Radja Grafindo Persada, 1999), h. 11.

${ }^{16}$ A. Rahmat Rosyadi dan H.M. Rais Ahmad, Formalisasi Syariat Islam...h. 73.
} 
Islamlah yang telah berhasil menjaga tetap utuhnya masyarakat Islam. Hukum Islam adalah aparat yang paling utama bagi kehidupan masyarakat Islam, jika telah menerima Islam sebagai agamanya, langsung mengakui dan menerima otoritas serta kekuatan mengikat hukum Islam terhadap diirinya.

\section{Analisis Filosofis Penerapan Hukum Islam}

Dalam kajian ilmu hukum pada umumnya, ada yang disebut hukum positif dan hukum yang di cita-citakan. Hukum positif adalah hukum yang sedang berlaku disuatu negara, sedangkan hukum yang di cita-citakan yaitu hukum yang hidup dimasyarakat, tetapi belum menjadi hukum positif secara legalformal. Eksistensi hukum Islam di Indonesia yang menjadi hukum positif hanya yang berkaitan dengan hukum privat, yaitu ubudiah dan muamalah. Sedangkan yang berhubungan dengan hukum publik Islam sampai saat ini masih menjadi hukum yang di cita-citakan.

Persoalan seputar penting tidaknya syariat Islam dilegislasikan menjadi hukum nasional merupakan satu wacana yang kerap melahirkan perdebatan yang cukup panjang. Pemikiran kearah itu banyak disampaikan oleh berbagai kalangan, walaupun dapat dipastikan bahwa pendapat para ahli tersebut banyak dipengaruhi oleh faktor-faktor politis, sosiologis, kultural, ideologis, dan religiositas.

Azyumardi Azra misalnya, dalam menanggapi soal kemungkinan positifasi hukum Islam menjadi hukum nasional, mengungkapkan bahwa yang harus diperhatikan adalah kondisi umat Islam Indonesia yang bukan merupakan realitas monolitik, tapi adalah realitas yang beragam, banyak golongannya, pemahaman keislamannya, keterikatannya, dan pengetahuannya yang berbedabeda. Realitas sosilogis ini dikhawatirkan akan menimbulkan persoalan viabilitas. Artinya hukum Islam tersebut tidak bisa bertahan, bahkan mungkin juga bisa menjadi kontraproduktif ketika lapisan masyarakat muslim yang pemahamannya terhadap Islam berbeda tadi kemudian tidak sebagaimana yang diharapkan. 
Selain itu, menurut Azyumardi Azra, perbedaan mazhab fikih juga perlu diperhitungkan, karena harus diakui bahwa di dalam soal fikih, khususnya mengenai hudud, terdapat perbedaan yang dari dulu sampai sekarang belum teratasi. Jadi, ada masalah secara internal di dalam fikih itu sendiri. Misalnya soal hudud, atau lebih spesifik lagi soal hukum rajam. Ada kalangan ulama misalnya Mahmud Syaltut berpendapat, hukum rajam adalah hukuman maksimal. Padahal kalau hukum rajam itu menjadi hukum yang maksimal, maka salah satu filsafat hukum yang merupakan inti dari filsafat hukum adalah menghindari semaksimal mungkin hukum yang maksimal. Karena kalau hukuman maksimal dijatuhkan maka fungsi aspek edukatif dari hukum itu menjadi hilang. Itu satu contoh yang perlu dipertimbangkan.

Juhaya S. Praja pendapatnya dalam merespon wacana dijadikannya hukum Islam sebagai penunjang pembangunan dalam kerangka sistem hukum nasional mengatakan bahwa walaupun dalam praktek tidak lagi berperan secara menyeluruh, hukum Islam masih memiliki arti besar bagi kehidupan pemeluknya. Setidaknya, ada tiga faktor yang menurut Juhaya Praja menyebabkan hukum Islam masih memiliki peranan besar dalam kehidupan bangsa.

Pertama, hukum Islam telah turut serta menciptakan tata nilai yang mengatur kehidupan umat Islam, minimal dengan menetapkan apa yang harus dianggap baik dan buruk, apa yang menjadi perintah, anjuran, perkenaan, dan larangan agama. Kedua, banyak keputusan hukum dan yurisprudensial dari hukum Islam telah diserap menjadi bagian hukum positif yang berlaku. Ketiga, adanya golongan yang masih memiliki aspirasi teokratis dikalangan umat Islam sehingga peranan hukum Islam secara penuh masih menjadi slogan perjuangan yang masih mempunyai pengaruh cukup besar. ${ }^{17}$

Pendapat yang berbeda disampaikan Habib Riziq Shihab, menurutnya penerapan hukum Islam harus formalistiklegalistik melalui institusi Negara. Ia

\footnotetext{
${ }^{17}$ Juhaya S. Praja, Hukum Islam di Indonesia, Pemikiran dan Praktik (Bandung: Rosda Karya, 1991), h. 15.
} 
mengatakan bahwa syariat Islam secara formal harus diperjuangkan dan harus diamalkan secara substansial. Tidak ada gunanya memperjuangkan formalitas sedangkan substansialnya ditinggalkan. Sebaliknya ia tidak setuju bila mengatakan yang penting substantinya, formalitasnya tidak perlu. Justru dengan formalisasi, maka substansi bisa diamalkan. Ia juga mengungkapkan pendapat Imam al-Ghazali yang berbicara tentang tata Negara Islam, bahwa "agama adalah fondasi, pemerintahan sebagai penjaganya. Apa-apa yang tidak ada fondasinya pasti rubuh dan apa-apa yang tidak dijaga pasti akan hilang.” Karenanya menurut Habib Riziq tidak boleh memisahkan agama dengan kekuasaan. ${ }^{18}$

Syariat Islam selama ini masih dipahami oleh sebagian orang sebagai hukum normatif yang tidak mempunyai sanksi yuridis atau kekuatan mengikat bagi masyarakat. Hukum yang bersifat normatif hanya dianggap sebagai patokan perilaku bagi seseorang dengan sanksi moral dari masyarakat. Hal itu menjadi kontraproduktif ketika bangsa ini hendak memberlakukan syariat Islam secara kaffah. Kesalahpahaman tersebut membuat syariat Islam hanya menjadi kekuatan moral ketimbang daya ikat hukum yang harus ditegakkan atau diberlakukan sebagai tuntutan akidah. Kekuatan syariat Islam dalam menata ketertiban dan kedamaian masyarakat selain yang bersifat normatif dalam bidang ubudiah dan muamalah, juga harus ditopang dalam bidang jinayah agar segala hak-hak masyarakat yang terampas bisa dikembalikan. Oleh karena itu, hukum pidana Islam sebagai hukum publik harus dilegislasi menjadi hukum positif. ${ }^{19}$

Berdasarkan pemikiran-pemikiran di atas, kami dapat mengatakan bahwa syariat Islam bukan hanya simbolisme ajaran moral yang dilaksanakan secara ritual saja, tetapi merupakan pragmatisme ajaran yang mesti diaplikasikan dalam kehidupan manusia.

\footnotetext{
${ }^{18}$ Lihat wawancara dengan Khamami Zadan dan Efendi Edyar bertajuk Jika Syariah Islam Jalan, Maka Jadi Negara Islam, dalam LAKPESDAM-TAF, Tashwirul Afkar (Jurnal Refleksi Pemikiran Keagamaan dan Kebudayaan), (Edisi No. 12, tahun 2002), h. 99-100.

${ }^{19}$ A. Rahmat Rosyadi dan H.M. Rais Ahmad, Formalisasi Syariat Islam...h. 96.
} 


\section{Faktor Peluang dan Tantangan Penerapan Pidana Islam}

\section{a. Faktor-faktor Pendukung Usaha Penerapan Pidana Islam}

Harapan untuk mengembangkan syariat Islam di Indonesia sudah lama terniatkan, sejak hukum pidana positif berkembang pada zaman pemerintahan Hindia Belanda. Para perumus bangsa (The Founding Fathers) sudah merencanakan untuk diberlakukannya syariat Islam di Indonesia. Namun, dengan mendasarkan pada pluralitas penduduk Indonesia, rencana itu tidak terwujud dan kemudian menjadian Pancasila sebagai dasar negara Indonesia. ${ }^{20}$

Penegakan hukum (kaidah) agama secara preventif ini sangat membantu pemantapan pola penegakan hukum (law enforcement) negara secara preventive represive. Tujuannya adalah agar masyarakat memahami dan menaati kaidah hukum negara dan kaidah agama sekaligus. Dengan demikian, syariah Islam bukan hanya didakwahkan, tetapi juga dilaksanakan melalui penegakan hukum preventif (bukan represif) guna mengisi kelemahan hukum pidana positif. ${ }^{21}$

Untuk Hukum Pidana Islam (HPI), yang menurut asas legalitas dikategorikan sebagai hukum tidak tertulis, masih dapat diakui di Indonesia secara konstitusional sebagai hukum, dan masih terus berlaku menurut pasal II Aturan Peralihan UUD 1945. Namun demikian, ketentuan dasar itu belum ditindaklanjuti dengan instrumen hukum untuk masuk ke dalam wujud instrumen asas legalitas. Seperti halnya KUHP di atas, posisi HPI belum terdapat kepastian untuk menjawab pertanyaan teoritis, mana hukum pidana yang dapat ditegakkan. ${ }^{22}$

Setidaknya ada beberapa hal yang menjadi modal atau kekuatan dalam usaha menuju penerapan syariat Islam yakni; (1) jumlah umat Islam cukup

20 Marzuki, Prospek Pemberlakuan Hukum Pidana Islam di Indonesia, http://eprints.uny.ac.id/2608/1/2._Prospek_Pemberlakuan_Hukum_Pidana_Islam_di_Indonesia.pd f, h. 10 diakses 12/9/2019.

${ }^{21}$ A. Malik Fajar, "Potret Hukum Pidana Islam; Deskripsi, Analisis Perbandingan dan Kritik Konstruktif'. Dalam Jaenal Aripin dan M. Arskal Salim GP (Ed.) Pidana Islam di Indonesia: Peluang, Prospek, dan Tantangan (Jakarta: Pustaka Firdaus, 2001), h. 18.

${ }^{22}$ Abdul Gani, "Eksistensi Hukum Pidana Islam dalam Reformasi Sistem Hukum Nasional”. Dalam Jaenal Aripin dan M. Arskal Salim GP (Ed.) Pidana Islam di Indonesia: Peluang, Prospek, dan Tantangan (Jakarta: Pustaka Firdaus, 2001), h. 246. 
signifikan; (2) maraknya gerakan-gerakan Islam yang senantiasa menyuarakan diterapkannya hukum Islam; (3) gagalnya beberapa sistem hukum dan bernegara yang bukan Islam telah memunculkan rasa frustasi umat manusia, sehingga mereka membutuhkan alternatif-alternatif yang lain. Di antara alternatif itu ialah Islam; (4) keberhasilan usaha-usaha politik dari kalangan Islam dan partai-partai politik Islam di beberapa negeri muslim; (5) sejarah umat Islam yang cemerlang di masa lampau ketika mereka menerapkan syariat Islam. Sejarah cemerlang ini setidak-tidaknya bisa memunculkan kerinduan-kerinduan pada benak umat Islam atas kembalinya masa kejayaan mereka. ${ }^{23}$

Peluang besar dalam penerapan hukum Islam secara utuh di Indonesia termasuk bidang pidana Islam menjadi impian besar. Hal itu didasari atas anggapan bahwa dengan diberlakukannya hukum pidana Islam, maka tindak pidana yang semakin hari semakin merebak di tengah-tengah masyarakat sedikit demi sedikit dapat diminimalisir. Kedatipun demikian hukum yang diterapkan di Indonesia khususnya dalam konteks pidana mempunyai relevansi dengan hukum pidana Islam. Misal, dalam hukum pidana Islam dikenal dengan hukum ta'zir, hukum yang ditetapkan berdasarkan pertimbangan penguasa dikarenakan tidak ditetapkannya dalam nash. Dalam konteks ke-Indonesiaan hukum ditetapkan oleh yudikatif dengan melakukan pertimbangan mendalam terkait dengan persoalanpersoalan hukum yang tidak ditemukan dalam hukum positif.

Hemat penulis bahwa penerapan hukum pidana Islam di Indonesia bukan tidak diterapkan, akan tetapi pada prinsipnya sejalan. Pemenuhan hak-hak di dalam hukum dan penerapan hukum ditunaikan berdasarkan kondisi lingkungan dan keadaan masyarakat Indonesia. Keadaan itu dalam penerapan hukum dikenal dengan istilah kontekstualisasi. Hal itu pun sejalan dengan konsep penerapan hukum yang dikemukankan oleh Ibnu Qayyim Al-Jauziyah bahwa hukum diterapkan berdasarkan keadaan, kondisi dan zamannya.

\footnotetext{
${ }^{23}$ H. Teuku Abdul Manan, Mahkamah Syar'iyah Aceh dalam Politik Hukum Nasional (Cet. I; Jakarta: Prenamedia, 2018), h. 243.
} 
b. Kendala-Kendala dalam Usaha Penerapan Syariat Islam

Ketiadaan HPI secara tertulis di Indonesia menjadi penyebab belum dapat terpenuhinya HPI secara legal sesuai dengan pertanyaan tersebut. Karena itulah HPI harus benar-benar disiapkan secara tertulis sebagaimana hukum positif lainnya, bukan langsung mendasarkannya pada sumber hukum Islam, yakni Alquran, Sunnah, dan ijtihad pada ulama (kitab-kitab fikih).

Hambatan eksternal berupa pihak-pihak yang memang sejak awal memiliki antipati terhadap Islam dan syariat Islam. Mereka adalah para pengusung agama dan ideologi tertentu diluar Islam, terutama yang memiliki pengalaman pahit melawan Islam. Mereka senantiasa menyebarluaskan imej yang negatif tentang Islam dan syariat Islam, misalnya dengan menjelek-jelekkan Islam dengan slogan "Harem dan Pedang" (sebagai simbol bagi pengungkungan kaum wanita dan kekerasan).

Hambatan dari pihak-pihak yang sebetulnya tidak terlalu ideologis kecuali bahwa mereka menolak penerapan syariat Islam karena akan mengekang kesenangan mereka. Mereka itulah yang sering disebut sebagai para hedonis, atau yang dalam bahasa Islam disebut sebagai ahlul ma'aashiy.

Hambatan dari pihak-pihak yang menolak syariat Islam karena belum memahami syariat Islam, atau memahaminya dengan pemahaman yang salah. Mereka inilah yang dalam bahasa Islam disebut sebagai ahlul jahl. Di samping itu, usaha-usaha menuju penerapan syariat Islam juga berkaitan dengan masalah strategi. Hambatan-hambatan bisa pula muncul dari pihak-pihak yang sudah sepakat dengan syariat Islam dan penerapannya, akan tetapi memiliki strategi yang berbeda-beda. Hambatan ini menjadi semakin signifikan apabila strategistrategi tersebut saling berseberangan satu sama lain. ${ }^{24}$

\footnotetext{
${ }^{24}$ H. Teuku Abdul Manan, Mahkamah Syar'iyah Aceh dalam Politik Hukum Nasional, h. 243-244.
} 


\section{PENUTUP}

Potret hukum pidana Islam yang dipahami sebagian orang adalah kejam dan tidak manusiawi, padahal kesan semacam itu muncul karena tidak melihat secara utuh dan menyeluruh. Hukum pidana Islam yang merupakan bagian dari syariat Islam, diterapkan bilamana sejumlah persyaratan yang ketat terpenuhi. Modal atau kekuatan dalam usaha menuju penerapan syariat Islam mempunyai peluang. Mayoritas masyarakat Indonesia adalah umat Islam, dan penyuaraan penerapan hukum Islam terus digalakkan. Selain itu, kontekstualisasi hukum pidana Islam dalam hukum ke-Indonesiaan mempunyai relasi kesesuaian. Tantangan besar dalam penerapan hukum pidana Islam adalam pluralisme masyarakat dan pemahaman masyarakat terhadap hukum Islam tidak secara menyeluruh (kaffah). 


\section{DAFTAR PUSTAKA}

Alquran dan Terjemahnya, Kementerian Agama RI.

Adams, Charles J. dalam Muhammad Daud Ali. Hukum Islam, Pengantar Ilmu Hukum dan Tata Hukum Islam di Indonesia. Cet. VII; Jakarta: Radja Grafindo Persada, 1999.

Fajar, A. Malik. "Potret Hukum Pidana Islam; Deskripsi, Analisis Perbandingan dan Kritik Konstruktif". Dalam Jaenal Aripin dan M. Arskal Salim GP (Ed.) Pidana Islam di Indonesia: Peluang, Prospek, dan Tantangan. Jakarta: Pustaka Firdaus, 2001.

Gani, Abdul. "Eksistensi Hukum Pidana Islam dalam Reformasi Sistem Hukum Nasional". Dalam Jaenal Aripin dan M. Arskal Salim GP (Ed.) Pidana Islam di Indonesia: Peluang, Prospek, dan Tantangan. Jakarta: Pustaka Firdaus, 2001.

Ichtijanto, H. S.A, Pengembangan Teori Berlakunya Hukum Islam di Indonesia, dalam: Hukum Islam di Indonesia, Perkembangan dan Pembentukan, Bandung: Remaja Rosdakarya, 1991.

Marzuki. Prospek Pemberlakuan Hukum Pidana Islam di Indonesia, http://eprints.uny.ac.id/2608/1/2._Prospek_Pemberlakuan_Hukum_Pidana _Islam_di_Indonesia.pdf, h. 10 diakses 12/9/2019.

Manan, H. Teuku Abdul. Mahkamah Syar'iyah Aceh dalam Politik Hukum Nasional. Cet. I; Jakarta: Prenamedia, 2018.

Rosyadi, A.Rahmat, dan H. M. Rais Ahmad, Formalisasi Syariat Islam dalam Perspektif Tata Hukum Indonesia, Edisi: I, Ghalia Indonesia, Bogor, April 2006.

Praja, Dr. Juhaya S. Hukum Islam di Indonesia: Pemikiran dan Praktek. Bandung: PT. Remaja Rosdakarya, 1991.

Salim, Arskal, Penerapan Syariat Bukan Negara Islam, dalam http://www.islamlib.com

Santoso, Topo. Membumikan Hukum Pidana Islam. Jakarta: Gema Inasani, 2003.

Thalib, Sayuti. Receptio a Contrario: Hubungan Hukum Adat dengan Hukum Islam. Jakarta: Bina Aksara, 1980.

Zadan, Khamami dan Efendi Edyar bertajuk Jika Syariah Islam Jalan, Maka Jadi Negara Islam, dalam LAKPESDAM-TAF, Tashwirul Afkar, (Jurnal Refleksi Pemikiran Keagamaan dan Kebudayaan), Edisi No. 12 tahun 2002. 